TEME, г. XLIV, бр. 4, октобар - децембар 2020, стр. 1245-1259

\begin{tabular}{lr}
\hline \hline Оригинални научни рад & https://doi.org/10.22190/TEME190626075R \\
Примљено: 26. 6. 2019. & UDK 159.944.4:371.275-057.875 \\
Ревидирана верзија: 11. 9. 2020. & 159.953 \\
Одобрено за штампу: 1. 12. 2020. &
\end{tabular}

\title{
COPING WITH TEST SITUATIONS AND EXAM PERFORMANCE AMONG STUDENTS
}

\author{
Milica Ristić*, Blagica Zlatković \\ University of Niš, Pedagogical Faculty, Vranje, Serbia \\ *milica.m82@gmail.com
}

\begin{abstract}
This study examined whether there were statistically significant differences in the level of expression of certain stress coping strategies during exam-taking among students. What was also tested was the correlation of coping strategies with the satisfaction with one's performance on the written exam, and also whether certain exam coping strategies and satisfaction with one's performance could be statistically significant predictors of the grade students obtained on the exam. The sample included 111 students (28 male and 83 female) attending the second year of the Pedagogical Faculty in Vranje. Before the written exam, the students completed the $\alpha$ scale from the KON6 test battery, which served as a measure of anxiety. The main idea in applying this scale was to assess whether students appraised the upcoming exam as a source of stress. Immediately after they finished the exam, they were given the Coping with test situation scale. In the end, the students were asked to rate how satisfied they were with their performance on the previously completed written exam. The results of ANOVA with repeated measures have shown that there was a statistically significant difference regarding the level of expression of certain stress coping strategies during the exam, where the most prominent was the problem-focused one. Satisfaction with one's performance on exam was in the statistically significant negative correlation with emotion-focused and imagination/distraction coping strategies. Statistically significant predictors of students' grades proved to be the satisfaction with their own test performance and imagination/distraction coping strategy. Although the results indicated that the problem-focused coping strategy is the most prominent one, the imagination/distraction coping strategy is the one that had the most influential negative impact on the exam performance.
\end{abstract}

Key words: $\quad$ stress coping strategies, exam situation, exam successfulness, problemfocused coping strategy.

\section{СУОЧАВАЊЕ СА ИСПИТНОМ СИТУАЦИЈОМ И УСПЕШНОСТ СТУДЕНАТА НА ИСПИТУ}

\section{Апстракт}

Циљ овог истраживања био је да се на узорку студената испита постојање статистички значајних разлика у степену изражености појединих стратегија суочавања 
са стресом изазваним испитном ситуацијом. Такође је испитана и корелација између стратегија суочавања са стресом и задовољства сопственим постигнућем на испиту, као и то да ли поједине стратегије суочавања са стресом и задовољство сопственим постигнућем на испиту могу бити статистички значајни предиктори оцене коју је студент добио на испиту. Узорком је обухваћено 111 студената друге године Педагошког факултета у Врању, при чему је 28 студената мушког пола, а 83 студента је женског пола. Као мера анксиозности коришћена је $\alpha$-скала из КОН6 батерије, коју су студенти попунили непосредно пре писменог испита. На основу резултата добијених на овој скали, испитано је да ли су студенти проценили предстојећу испитну ситуацију као извор стреса. Након завршеног испита, студентима је задата Скала суочавања са испитном ситуацијом. На крају, студенти су добили задатак да процене колико су задовољни тиме како су урадили писмени испит. Резултати Анове са поновљеним мерењем указали су на постојање статистички значајних разлика у изражености појединих стратегија суочавања са стресом у испитној ситуацији, при чему је најизраженије било суочавање усмерено на проблем. Показало се и да је задовољство студената тиме како су урадили писмени испит у статистички значајној негативној корелацији са суочавањем које је усмерено на емоције и суочавањем маштање/дистракција. Као статистички значајни предиктори оцене на испиту показали су се задовољство урађеним на испиту и стратегија суочавања маштања/дистракција. Могло би се рећи да, иако су резултати указали на то да је суочавање усмерено на проблем најизраженије код студената, суочавање маштање/дистракција је оно које има најнегативнији утицај на успех (субјективно и објективно процењен) на испиту.

Кључне речи: стратегије суочавања са стресом, испитна ситуација, успех на испиту, суочавање усмерено на проблем.

\section{INTRODUCTION}

Stress and anxiety, but especially strategies that people use in order to cope with them, are important factors that in many ways determine the performance and achievement in various fields of everyday life. Depending on their theoretical orientations, different authors explain stress in different ways. Currently, the most prominent models are oriented on the transaction processes between the person and their environment in stressful situations. According to Calsbeek, Rijken, Bekkers, Van Berge Henegouwen, and Dekker (2006), most studies on coping with daily stressors and problems use the transactional model of Lazarus and Folkman as a frame of reference.

Lazarus and Folkman (e.g. Folkman \& Lazarus, 1988; Lazarus, 1999; Lazarus \& Folkman, 1984; Lazarus \& Folkman, 1987) proposed one of the most comprehensive theories of stress and coping - the Transactional theory of stress and coping. Lazarus (e.g. Lazarus, 1999) explains that stress represents a product of a transaction between an individual (including multiple personal systems) and his or her complex environment (Lazarus \& Folkman, 1984). Events or situations are not inherently stressful - an individual's subjective judgment of the situation as threatening or harmful is what defines a stressor. In other words, how an individual appraises a stressor determines how he or she copes with or responds to the stressor (Folkman \& Lazarus, 1988; Lazarus \& Folkman, 1987). 
Stress coping implies a process of cognitive appraisal to determine whether an individual believes he or she has the resources to respond effectively to the challenges of a stressor or change (Folkman \& Lazarus, 1988; Lazarus \& Folkman, 1987). According to Compas, Connor-Smith, Saltzman, Thomsen, and Wadsworth (2001) the most widely cited definition of coping is that of Lazarus and Folkman. Lazarus and Folkman (Lazarus \& Folkman, 1984, p. 141) defined coping as:

constantly changing cognitive and behavioral efforts to manage specific external and/or internal demands that are appraised as taxing or exceeding the resources of the person.

Their model of stress appraisal includes primary, secondary, and reappraisal components (e.g. Lazarus \& Folkman, 1984).

In the primary appraisal, a person determines whether an encounter is irrelevant, benign-positive, or stressful. Stressful appraisals are characterized by threat, challenge, or harm-loss (e.g. Folkman \& Lazarus, 1985; Folkman, Lazarus, Dunkel-Schetter, DeLongis, \& Gruen, 1986).

Primary appraising has to do with whether or not what is happening is relevant to one's values, goal commitments, beliefs about self and world, and situational intentions (Lazarus, 1999, p.75).

Among them, Lazarus claims that goal commitment is the most powerful factor in determining actions. In the secondary appraisal, the person evaluates whether he or she can cope with the perceived change adequately.

Secondary appraising refers to a cognitive-evaluative process that is focused on what can be done about a stressful person-environment relationship, especially when there has been a primary appraisal of harm, threat, or challenge (Lazarus, 1999, p.76).

Two major functions of coping are determined as problem and emotion-focused. In their research on a middle-aged community sample, Folkman and Lazarus (1980) found that Problem-focused coping was used more frequently in encounters that were appraised as changeable, and in those appraised as unchangeable, emotion-focused coping was used more frequently. If the individual does not believe in having the resources to respond to the challenge or feels a lack of control, he or she is most likely to turn to an emotion-focused coping response, state Lazarus and Folkman (1984). On the contrary, if the person believes in her/his own resources to manage the challenge, he or she will usually develop a problem-focused coping response. In that way, according to Lazarus and Folkman (1984), the function of coping responses is to extenuate negative emotions provoked by a stressful situation or to act on the stressors and their source. Some of the strategies or responses in the problem-focused coping domain are defining the problem, seeking information, planning, finding possible 
solutions, putting effort and trying to change circumstances that are the source of stress. Emotion-focused coping involves strategies such as avoiding the source of stress, positive reappraisal and seeking social support. Nevertheless, Lazarus and Folkman (1984) assume that both strategies could be helpful in managing stress in the same situation and that person can use the same strategies in different situation or even in the different phases of a single stressful situation, i.e. "No universally effective or ineffective coping strategy exists" (Lazarus, 1999, p. 111).

After Lazarus and Folkman developed their model and associated measure, new theoretically and factor-based classifications emerged. For example, Endler and Parker's (1990) measure of coping consists of three subscales. Beside the above-mentioned problem-focused and emotionfocused, there is the avoidance-oriented coping. This strategy includes either the use of person-oriented or task-oriented strategies aimed to circumvent or avoid stressful conditions. Further, Moos, Brennan, Fondacaro, and Moos (1990) reasoned that researchers have used two main conceptual approaches to classify coping responses. One of them emphasizes the focus of coping (problem or emotion-focused), and the other one is concerned about the method of coping (cognitive or behavioral). The authors combined these two approaches and proposed four sets of coping responses: approach-cognitive, approach-behavioral, avoidance-cognitive, and avoidance-behavioral. More recently, Zuckerman and Gagne (2003) developed an inventory of coping strategies (R-COPE) and based on the factor analysis found five dimensions: self-help, approach, accommodation, avoidance, and self-punishment.

Folkman and Lazarus (1985) additionally proposed criteria that must be fulfilled in order to study coping as a process. First, coping must be examined within the situational specific context. Next, it is important to investigate what a person actually does, not what the person usually does, or would do, and finally, in order to examine changes in coping over time as the event unfolds, multiple assessments are required. Considering the numerous studies on a subject of coping strategies and its measures, it could be noticed that the measures of coping with specific stressful situations are very rare, states Lončarić (2006). He further explains that the majority of the scales developed for studying stress in a school context are mainly various scales constructed as measures of adult coping with a wide range of different, nonspecific situations. On the other hand, there are also instruments constructed in that way that changing test instruction also means changing its purpose. However, according to Lončarić (2006), there are few scales, like Sorić's (2002) Coping with test situation scale, that are context-specific.

Sorić herself (2002) claims that among numerous scales developed for measuring coping with different kinds of situations, none of them is purposefully constructed to asses coping in the specific school situation of written knowledge examination. For that purpose, she developed Coping with test situation scale and based on the factor structure analysis extracted 
for subscales: emotion-focused, problem-focused, imagination/distraction, and assistance seeking. The problem-focused strategy involves activities aimed to manage or solve the problem and directly act on the perceived stressor - in this case by concentrating on the exam questions, careful deliberation, and planning. The emotion-focused strategy involves tendencies to reduce emotional distress and maintain satisfactory internal state for processing information and actions. Imagination/distraction coping strategy is similar to Endler and Parker's (1990) description of avoidance-oriented coping by task-oriented strategies (or engaging in non-relevant tasks). The assistance seeking subscale, as the name implies, means that students seek help from external sources - mostly the usage of illegal means (like copying from others).

According to Sorić (1999), one of the most common evaluative situations in which individual achievement is continuously evaluated and judged according to the program criteria, is the school situation. Since these criteria are most frequently the basis of selection, they function as a "filter" for advancing the successful students, and for "blocking" those who have not succeeded. In this way, they have serious implications for an individual and his/her future.

When faced with stressful assessment situations, in order to cope, students use strategies with different levels of effectiveness. Some of them lead students to study and work toward their goals effectively, deal with the stress of assessment, and achieve positive outcomes, while others lead students to more ineffective study strategies, and maladaptive behaviors such as procrastination and avoidance. Doron, Stephan, Boiché, and Scanff (2009) summarize the results of past studies on different kinds of strategies that students use to face exam-related stress. According to them, these strategies can be categorized as problem-focused, involving activities cantered on changing the stressful situation or emotion-focused, involving activities focused on modifying one's reactions to stressful situations (e.g. positive reinterpretation). Here, in general, problem-focused coping responses yielded more positive outcomes, and certain emotion-focused coping responses have been viewed as maladaptive because they may lead one to disengage from the task.

Struthers, Perry, and Menec (2000) in their research found that lower grades were associated with greater academic-related stress. Genc (2017) found that coping mechanisms proved to be direct predictors of academic success. Coping strategies of planning and seeking social support for instrumental purposes have also been proven to be significantly related to self-efficacy, at least among first-year undergraduate students (Devonport \& Lane, 2006). Moreover, Crego, Carrillo-Diaz, Armfield, and Romero (2016) in their research found that rational coping strategies were positively and emotional coping strategies negatively associated with students' examrelated self-efficacy and also, those students who perceived themselves as more efficient in completing examinations reported better grades. 
According to Cohen, Ben-Zur, and Rosenfeld (2008), setting clear goals, focusing one's attention, and increasing efforts to avoid errors while solving problems (all of which are forms of active task-focused coping) regularly display a direct positive correlation with better exam achievement. The results of their research showed that problem-focused coping contributed positively to performance on the test, and avoidance coping adversely affected test grades. Stöber and Pekrun (2004) additionally explain the reason why the test coping strategies deserve to be examined more thoroughly - inappropriate coping strategies used by students could often mask their real potential.

\section{AIMS}

For the current research, the following goals were set. First, to investigate whether there was a difference in the level of expression of certain exam coping strategies among students. The correlation of coping strategies with satisfaction with one's performance on the written exam was also tested. Finally, it was examined whether certain exam coping strategies and the satisfaction with one's performance could serve as statistically significant predictors of the grade students obtained on the exam.

\section{METHODS}

\section{Participants and Procedure}

The sample included 111 students ( 28 boys and 83 girls) in the second year of the Pedagogical Faculty in Vranje. Before the written exam started, students had been given the $\alpha$ scale form the KON6 battery as a measure of anxiety. The main idea in applying this scale was to assess whether students appraised an upcoming event as a source of stress. Immediately after they had completed the written exam, students completed the Coping with test situation scale. In the end, students were asked to, rate (on the scale from 1 to 5), how satisfied they were with their performance on the previously completed written exam.

\section{Instruments}

The Coping with test situation scale (Sorić, 2002) consists of 25 items, which served to measure four coping strategies subscales: emotionfocused ( 7 items), problem-focused ( 8 items), imagination/distraction (7 items) and assistance seeking ( 3 items). Based on her sample, Sorić reports that the internal consistency for each of the four subscales was satisfactory. The assessment of the internal consistency on the current sample showed that it was also acceptable. Cronbach's alpha was measured at .81 for the emotion-focused subscale, at .79 for both the problem-focused and 
imagination/distraction subscales and at .69 for the assistance seeking subscale.

The a scale from the KON6 test battery (Momirović, Wolf \& Džamonja, 1992) consists of 30 Likert type scale 5-point items (Cronbach's alpha $=.92)$. Alpha is one of the six systems that regulates an individual's functioning and represents the System for the regulation of defense reactions. The results of dysfunction of this system are different modalities and symptoms of anxiety (Momirović, Horga, \& Bosnar, 1982; Momirović, Horga, \& Bosnar, 1984). One of the main reasons for choosing this scale as an instrument for measuring anxiety in the current research is the fact that it has already been standardized for the Serbian population.

\section{RESULTS}

Results on the level of expression of anxiety on the current and normative sample (Momirović, Volf, \& Džamonja, 1992) are given in Table 1.

Table 1. Level of anxiety

\begin{tabular}{lccc}
\hline & Mean & Std. Deviation & $\mathrm{N}$ \\
\hline Current sample & 94.8 & 22.743 & 111 \\
Normative sample & 76.7 & 22.95 & 772 \\
\hline
\end{tabular}

The $t$ test results confirmed that prominence of anxiety in a current sample is above the average obtained on a normative sample $(\mathrm{t}(881)=7,778$, $p<.0001)$.

Descriptive statistics results on exam grades and students' satisfaction with their exam performance are presented respectively in Table 2 and Table 3

Table 2. Obtained grades

\begin{tabular}{ccccc}
\hline Grade & Frequency & Percent & Valid Percent & Cumulative Percent \\
\hline 5 & 60 & 54,1 & 54,1 & 54,1 \\
6 & 19 & 17,1 & 17,1 & 71,2 \\
7 & 18 & 16,2 & 16,2 & 87,4 \\
8 & 9 & 8,1 & 8,1 & 95,5 \\
9 & 5 & 4,5 & 4,5 & 100,0 \\
\hline $\mathrm{N}$ & 111 & 100,0 & 100,0 & \\
\hline
\end{tabular}


Table 3. Students satisfaction with own exam performance

\begin{tabular}{cccc}
\hline Satisfaction & Frequency & Percent & Cumulative Percent \\
\hline 1 & 8 & 7,2 & 7,2 \\
2 & 13 & 11,7 & 18,9 \\
3 & 36 & 32,4 & 51,4 \\
4 & 47 & 42,3 & 93,7 \\
5 & 7 & 6,3 & 100,0 \\
\hline Total & 111 & 100,0 & \\
\hline
\end{tabular}

Legend: 1 - not satisfied at all; 2 - not satisfied; 3 - neither dissatisfied neither satisfied; 4 - satisfied; 5 - completely satisfied

As it could be seen from the results presented in the Table 2, the majority of students $(54,1 \%)$ did not pass the exam and none of them obtained the highest grade (10). $42,3 \%$ of students stated that they were satisfied with how they did on the written exam (Table 3), and 6.3 that they are completely satisfied.

Table 4 contains the results on the level of expression of certain exam coping strategies.

Table 4. Level of expression of exam coping strategies

\begin{tabular}{lcccc}
\hline & Min & Max & Mean & Std. Deviation \\
\hline Emotion-focused & 1.14 & 5.00 & 3.107 & .909 \\
Problem-focused & 1.50 & 5.00 & 3.685 & .737 \\
Imagination/distraction & 1.00 & 4.71 & 2.778 & .936 \\
Assistance seeking & 1.00 & 5.00 & 1.871 & .860 \\
\hline $\mathrm{N}$ & 111 & & & \\
\hline
\end{tabular}

The results of ANOVA with repeated measures shows that there was a statistically significant difference regarding the level of expression of certain coping strategies $(\mathrm{F}(3,330)=100.836, p<.001)$. The results of a post hoc test (Fisher's least significant difference procedure) are presented in Table 5.

Table 5. Differences in the level of expression of the exam coping strategies

\begin{tabular}{llcc}
\hline Exam coping strategies & & Mean Diff. & Std. Error \\
\hline Emotion-focused & Problem-focused & $-.578^{*}$ & .090 \\
& Imagination/distraction & $.329^{*}$ & .087 \\
& Assistance seeking & $1.236^{*}$ & .120 \\
Problem-focused & Imagination/distraction & $.907^{*}$ & .116 \\
& Assistance seeking & $1.814^{*}$ & .120 \\
Imagination/distraction & Assistance seeking & $.906^{*}$ & .103 \\
\hline
\end{tabular}

The mean difference is significant at the .05 level. 
The results of the post-hoc test show that the most prominent is the problem-focused coping strategy and that the least expressed one is the assistance seeking one (Table 5).

The correlations of exam coping strategies with satisfaction with exam performance were also investigated. The obtained results indicated that satisfaction with one's performance is in the statistically significant negative correlation with Emotion-focused $(\mathrm{r}=-0.191, \mathrm{p}<.05)$ and Imagination/ distraction $(r=-0.207, p<.05)$ coping strategies.

Finally, it was investigated whether certain exam coping strategies and satisfaction with their own performance could be statistically significant predictors of the grade students obtained on the exam. Regression analysis results are presented in Table 6 .

Table 6. Predictors of exam grade - results of regression analysis

\begin{tabular}{lccc}
\hline Predictors & Model summary & $\beta$ & $\mathrm{p}$ \\
\hline Performance satisfaction & & $\mathbf{. 2 3 2}$ & $<.05$ \\
Emotion-focused & $\mathrm{R}=.333 ; \mathrm{R}^{2}=.111 ; \Delta \mathrm{R}^{2}=$ & .121 & .527 \\
Problem-focused & .069 & .017 & .816 \\
Imagination/distraction & $\mathrm{F}(5,110)=2.626 ; \mathbf{p}<. \mathbf{0 5}$ & $\mathbf{- . 2 4 1}$ & $<.05$ \\
Assistance seeking & & .011 & .752 \\
\hline
\end{tabular}

Note. R - Multiple Correlation Coefficient;

$\mathrm{R}^{2}$ - coefficient of multiple determination; $\Delta \mathrm{R}^{2}$ - adjusted coefficient of multiple determination; $B$ - standardized regression coefficient

Results showed that the predictive model is statistically significant and that the combination of predictors explains $11.1 \%$ of the total variance of the grade obtained in the exam. Statistically significant predictors proved to be satisfaction with their performance as positive and coping strategy Imagination/distraction as a negative one.

\section{DISCUSSION}

One of the main goals of this investigation was to examine whether there was a difference in the level of expression of certain exam coping strategies among students. Primarily, the above-average result on the $\alpha$ scale directs toward a presumption that the upcoming exam initiated students' defense reactions, i.e. that they experienced a kind of pre-exam anxiety. This result gave initial justification for further data analysis, because it confirmed that students appraised the testing situation as stressful. The results of the repeated measures ANOVA that served to test the differences in the expression of the Exam coping strategies subscales, proved to be significant. The most prominent one was the problem-focused strategy, followed by Emotion-focused, while the least expressed was the assistance seeking strategy. Vranješ (2012) conducted an investigation 
with the identical instrument as the one that was used in this research, and her results matched those obtained here. With the same instrument, Beara and Bajić (2014) replicated this result. Zeidner's (1996) research data also showed that students employed significantly more problem-focused responses than emotion-focused coping and more problem-focused than avoidance coping responses. This result is also in line with the idea that expected stressful events (in this case exams), compared to unexpected ones, are perceived as more under control, so that in those situations people tend to use problem focused coping strategies (Compas et al., 2001; Folkman, 1984).

Results also indicated that satisfaction with one's performance was in the statistically significant negative correlation with Emotion-focused and Imagination/distraction coping strategies. In other words, the more students involved themselves in strategies whose aim was to affect the emotional arousal associated with the stressful situation (e.g. trying to manage feelings of anxiety, nervousness, and helplessness), or in those strategies which distanced them from the task, the less they were satisfied with their performance. Similarly, Crego et al. (2016) came to the results that emotional coping strategies are negatively associated with students' exam-related self-efficacy. After introducing various results, Brougham, Zail, Mendoza, and Miller, J. R. (2009) infer that, in general, avoidance and emotional expression as college students' coping strategies in response to stress were found to be maladaptive. This conclusion is also in accordance with the result obtained in current research on the correlation of anxiety and these coping strategies, which was found to be statistically significant and positive.

The results of linear regression analysis showed that two independent variables were significant contributors to the prediction of students' grades satisfaction with one's own performance and Imagination/distraction coping strategy. In the proposed regression model, as expected, Performance satisfaction proved to be positively correlated to the obtained grade. In line with this finding are the results of Crego et al. (2016) who concluded that those students who perceived themselves as more efficient in completing examinations reported better grades. Imagination/distraction coping strategy proved to be the negative correlate of the obtained grade in current research, and the same result on the relation of these coping strategies with academic achievement were obtained by Vranjes (2012). In their research Folkman and Lazarus (1985) confirmed that imagination coping strategy was related to lower exam grades. Cohen et al. (2008) obtained the similar result that avoidance coping (imagination and distraction could be seen as a form of avoidance) adversely affected test grades.

Doron et al. (2009) review of the previous studies results should also be mentioned here. Namely, they argued that those results, in general, indicated that problem-focused coping responses yielded more positive 
outcomes. In the case of the current study, no such evidence was found. Considering the highest level of expression of the problem coping strategies, one could expect that students' grades should be far better. Besides that, although more than $50 \%$ of them did not pass the exam and none of them got the highest grade (10), only $18,9 \%$ of them, immediately after the exam was finished, stated that they were not satisfied with how they did.

Spielberger and Vagg's (1995, cited in Genc, 2014) in their Transactional Process Model of exam anxiety claim that the student perceives the exam situation through his subjective prism and accordingly experiences it as more or less threatening. That depends on his personal characteristics, but also on the situational characteristics (such as attitudes, skills and competencies of learning and exam-taking), which could largely determine how much a student is prepared for the exam and how he perceives and estimates his possibilities for satisfactory achievement. In that context, some questions lack an answer here. The first is how hard students studied for the upcoming exam. Besides that, the meaning of "satisfactory" could vary from one student to another. The students who did not even expect to pass the exam, were satisfied with their achievement considering the time and effort they put in the exam preparation.

Also, one must bear in mind the process of secondary appraisal.

Secondary appraisal activity is a crucial feature of every stressful encounter because the outcome depends on what, if anything, can be done, as well as on what is at stake (Lazarus \& Folkman, 1984, p. 35).

Therefore, secondary appraisal process outcomes could be quite different from those of primary appraisal. As Zeidner (1995) stated “...to truly understand coping with exams, we need to understand the main threat meanings of a particular examination context" (p. 129). In this case, it was the first of three examination periods in the school year, so students had chances to retake it. In other words, stakes were low. Associated with all the above mentioned is the obtained result about the least prominence of assistance seeking coping strategy. Considering that this subscale contains questions that imply using illegal means (like coping from others), one could raise doubt about the students' deliberate and honest answering.

The general inference that could be drawn from this research is that although the obtained results indicated that the problem-focused strategy is the most prominent one, the imagination/distraction strategy is the one that had the most influential negative impact on exam performance. No matter the explanation here, it is important to have in mind Berry and Kingswell's (2012) remark that, although coping strategies can be different across and within situations, individuals may have the tendency to use habitual methods of coping. As a part of improving the academic potential of students, Berry and Kingswell (2012) stress the importance of identifying those who are prone to engage in maladaptive strategies of coping with 
exam-related stress and second to help them develop more functional methods. For example, the seemingly superficial intervention of writing about testing worries immediately before taking a test, significantly improved the students' exam scores, especially for those habitually anxious about testtaking (Ramirez \& Beilock, 2011). Educational institutions, before all, should and must be the main propagators in processes of making students more conscious about strategies they use when facing the exam situation and teaching them to use the more appropriate ones.

Limitations and conclusions. Giving socially desirable answers is one of the problems pestering almost all studies based on self-report questions. Nevertheless, current results markedly differ from those commonly obtained in various studies that Problem-focused strategies have a positive effect on performance. As it was already mentioned, at least two questions lack answers: How hard did the students prepare for the upcoming exam? and What does satisfactory mean for each of them? Besides that, coping is a process comprised of different phases, so there is always a possibility that coping strategies used in the situation of actually taking the exam are quite different from those appraised as commonly used in the exam situation after it was finished. In that context, post-exam anxiety results should also be included in future research.

The sample size and its convenience certainly do not allow the generalization of the results. However, the data obtained here have the potential to point out the possible directions for developing strategies aimed to help students to deal with exams more efficiently and generally with those situations in life, which require some kind of evaluation.

\section{REFERENCES}

Beara, M., \& Bajić, G. R. (2014). Primarna i sekundarna kontrola i suočavanje sa ispitnom situacijom. Tematski zbornik radova Departman za psihologiju Individualne razlike, obrazovanje i rad, 37-47. Filozofski fakultet, Univerzitet u Nišu

Berry, K., \& Kingswell, S. (2012). An investigation of adult attachment and coping with exam-related stress. British Journal of Guidance \& Counselling, 40(4), 315-325. doi: 10.1080/03069885.2012.685861

Brougham, R. R., Zail, C. M., Mendoza, C. M., \& Miller, J. R. (2009). Stress, Sex Differences, and Coping Strategies among College Students. Current psychology, 28(2), 85-97. doi: 10.1007/s12144-009-9047-0

Calsbeek, H., Rijken, M., Bekkers, M. J., Van Berge Henegouwen, G. P., \& Dekker, J. (2006). Coping in adolescents and young adults with chronic digestive disorders: impact on school and leisure activities. Psychology and Health, 21(4), 447-462. doi: 10.1080/14768320500410910

Crego, A., Carrillo-Diaz, M., Armfield, J. M., \& Romero, M. (2016). Stress and Academic Performance in Dental Students: The Role of Coping Strategies and ExaminationRelated Self-Efficacy. Journal of dental education, 80(2), 165-172.

Cohen, M., Ben-Zur, H., \& Rosenfeld, M. J. (2008). Sense of coherence, coping strategies, and test anxiety as predictors of test performance among college students. 
International Journal of Stress Management, 15(3), 289. doi: 10.1037/1072-5245. 15.3.289

Compas, B.E., Connor-Smith, J.K., Saltzman, H., Thomsen, A.H., \& Wadsworth, M.E (2001). Coping with Stress during Childhood and Adolescence: Problems, Progress an Potential in Theory and Research. Psychological Bulletin, 127(1), 87-127. doi: 10.1037//0033-2909.127.1.87

Devonport, T. J., \& Lane, A. M. (2006). Relationships between self-efficacy, coping and student retention. Social Behavior and Personality: an international journal, 34(2), 127-138. doi: 10.2224/sbp.2006.34.2.127

Doron, J., Stephan, Y., Boiché, J., \& Scanff, C. L. (2009). Coping with examinations: Exploring Relationships between Students' Coping Strategies, Implicit Theories of Ability, and Perceived Control. British Journal of Educational Psychology, 79(3), 515-528. doi: 10.1348/978185409X402580

Endler, N. S., \& Parker, J. D. (1990). Multidimensional assessment of coping: A critical evaluation. Journal of personality and social psychology, 58(5), 844854. doi: 10.1037/0022-3514.58.5.844

Folkman, S. (1984). Personal control and stress and coping processes: A theoretical analysis. Journal of personality and social psychology, 46(4), 839-852. doi: 10.1037/0022-3514.46.4.839

Folkman, S., \& Lazarus, R. S. (1980). An Analysis of Coping in a Middle-Aged Community Sample. Journal of health and social behavior, 21(3), 219-239. doi: $10.2307 / 2136617$

Folkman, S., \& Lazarus, R. S. (1985). If it changes it must be a process: study of emotion and coping during three stages of a college examination. Journal of personality and social psychology, 48(1), 150-170. doi: 10.1037/0022-3514.48.1.150

Folkman, S., \& Lazarus, R. S. (1988). Coping as a mediator of emotion. Journal of personality and social psychology, 54(3), 466. doi:10.1037/0022-3514.54.3.466

Folkman, S., Lazarus, R. S., Dunkel-Schetter, C., DeLongis, A., \& Gruen, R. J. (1986). Dynamics of a stressful encounter: cognitive appraisal, coping, and encounter outcomes. Journal of personality and social psychology, 50(5), 992-1003. doi: $10.1037 / 0022-3514.50 .5 .992$

Genc, A. (2014). Relacije između stres-procesa $i$ ispitne anksioznosti-distorzije $u$ sećanjima na emocije iz prošlih stresnih transakcija (Relationships between the stress-process and test anxiety - distortions in memory for emotions from past stressful transactions). Doktorska disertacija. Filozofsku fakultet, Univerzitet u Novom Sadu, Novi Sad.

Genc, A. (2017). Coping strategies as mediators in the relationship between test anxiety and academic achievement. Psihologija, 50(1), 51-66. doi: 10.2298/ PSI160720005G

Lazarus, R. S. (1999). Stress and emotion: A new synthesis. Springer Publishing Company.

Lazarus, R. S., \& Folkman, S. (1984). Stress, appraisal, and coping. New York: Springer

Lazarus, R. S., \& Folkman, S. (1987). Transactional theory and research on emotions and coping. European Journal of personality, 1(3), 141-169. doi: 10.1002/per. 2410010304

Lončarić, D. (2006). Suočavanje učenika s akademskim i interpersonalnim stresnim situacijama: provjera međusituacijske stabilnosti strategija suočavanja [Students Coping with Academic and Interpersonal Stressors: Testing Cross-Situational Stability of Coping Strategies]. Psihologijske teme, 15(1), 25-58.

Momirović, K., Horga, S., \& Bosnar, K. (1982). Prilog formiranju jednog kibernetičkog modela strukture konativnih faktora [An addition to formation of one cybernetic model of a structure of conative factors]. Kineziologija, Zagreb, 14, 83-108. 
Momirović, K., Horga, S., \& Bosnar, K. (1984). O mogućnosti sinteze nekih teorija ličnosti na temelju jednog kibernetičkog modela konativnih faktora [On a possibility of a synthesis of some personality theories on the grounds on one cybernetic model of conative factors]. Čovek i zanimanje, 28, 3-6.

Momirović, K., Volf, B., \& Džamonja, Z. (1992). KON 6 - kibernetickka baterija konativnih testova [KON 6 - cybernetic battery of conative tests]. Beograd: CPP.

Moos, R. H., Brennan, P. L., Fondacaro, M. R., \& Moos, B. S. (1990). Approach and Avoidance Coping Responses among Older Problem and Nonproblem Drinkers. Psychology and aging, 5(1), 31. doi: 0882-7974/90/SOOJ5

Ramirez, G., \& Beilock, S. L. (2011). Writing about Testing Worries Boosts Exam Performance in the Classroom. Science, 331(6014), 211-213. doi: 10.1126/science. 1199427

Sorić, I. (1999). Anxiety and coping in the context of a school examination. Social Behavior and Personality: an international journal, 27(3), 319-330. doi: 10.2224/ sbp.1999.27.3.319

Sorić, I. (2002.). Skale suočavanja s ispitnom situacijom [Coping with test situation scale]. In Zbirka psihologijskih skala i upitnika, svezak, 1 (K. Lacković-Grgin, A, Proroković, V Cúbela i Z. Penezić (Eds.). Zadar: Filozofski fakultet, 151-154.

Stöber, J., \& Pekrun, R. (2004). Advances in test anxiety research. Anxiety, Stress and Coping, 17, 205-211. doi: 10.1080/1061580412331303225

Struthers, C. W., Perry, R. P., \& Menec, V. H. (2000). An Examination of the Relationship among Academic Stress, Coping, Motivation, and Performance In College. Research in higher education, 41(5), 581-592. doi: 10.1023/A:1007094931292

Zeidner, M. (1995). Adaptive coping with test situations: A review of the literature. Educational Psychologist, 30(3), 123-133. doi: 10.1207/s15326985ep3003_3

Zeidner, M. (1996). How do high school and college students cope with test situations? British Journal of Educational Psychology, 66(1), 115-128. doi: 10.1111/j.2044-8279.1996.tb01181.x

Zuckerman, M., \& Gagne, M. (2003). The COPE revised: Proposing a 5-factor model of coping strategies. Journal of Research in Personality, 37(3), 169-204. doi: 10.1016/S0092-6566(02)00563-9

Vranješ, V. (2012). Načini suočavanja s ispitnom situacijom, akademsko postignuće i učestalost negativnih automatskih misli kod studenata [Students' ways of coping with test situation, academic achievement and frequency of negative automatic thoughts]. Diplomski rad. Filozofsku fakultet u Osijeku, Sveučilište Josipa Jurja Strossmayera, Osijek.

\title{
СУОЧАВАЮЕ СА ИСПИТНОМ СИТУАЦИЈОМ И УСПЕШНОСТ СТУДЕНАТА НА ИСПИТУ
}

\author{
Милица Ристић, Благица Златковић \\ Универзитет у Нишу, Педагошки факултет Врању, Република Србија
}

\section{Резиме}

Када се нађу у стресној ситуацији која подразумева неку врсту процене, као што је то ситуација полагања испита, студенти користе различите стратегије суочавања са стресом, чија ефикасност може бити различита. Неке од ових стратегија помажу им у превазилажењу стреса у ситуацији процењивања и усмеравају их ка долажењу 
до позитивног исхода, док друге могу укључивати маладаптивна понашања, као што су одвлачење пажње и избегавање.

Лазарус и Фолкман (Lazarus \& Folkman, 1984, p. 141) дефинишу превладавање као „стално мењање когнитивних и бихевиоралних напора како би се изашло на крај са специфичним спољашњим и/или унутрашњим захтевима који се процењују као оптерећујући или толико тешки да превазилазе ресурсе којима особа располаже”. Две главне функције превладавања (суочавања) одређене су као усмерене на емоције и усмерене на проблем. Према Лазарусу и Фолкману (Lazarus and Folkman, 1984), уколико особа не верује да поседује ресурсе да адекватно одговори на захтеве ситуације коју је проценила као стресну или осећа недостатак контроле, та особа ће највероватније применити суочавање усмерено на емоције. У супротном, уколико особа има вере у сопствене капацитете да изађе на крај са изазовом, вероватно је да ће њен одговор бити суочавање усмерено на проблем. Циљ овог истраживања био је да се испита постојање статистички значајних разлика у степену изражености појединих стратегија суочавања са испитном ситуацијом међу студентима. Такође је испитана корелација стратегија суочавања са задовољством сопственим постигнућем, као и да ли поједине стратегије суочавања и задовољство сопственим постигнућем могу бити статистички значајни предиктори оцене коју је студент добио на испиту. Узорак је обухватио 111 студената друге године Педагошког факултета у Врању, при чему је 28 студената мушког пола и 83 студента женског пола. Као мера анксиозности, чија је основна намена била да се провери да ли су студенти проценили испитну ситуацију као стресну, коришћена је $\alpha$-скала из КОН6 батерије (Momirović, Wolf and Džamonja, 1992), коју су студент попунили непосредно пре испита. Након завршеног писменог испита, студентима је задата Скала суочавања са испитном ситуацијом (Sorić, 2002). Ова скала је наменски конструисана за процену стратегија суочавања у специфичној ситуацији писменог испитивања знања у школи и састоји се из четири супскале: суочавање усмерено на емоције, суочавање усмерено на проблем, имагинација/дистракција, тражење помоћи. На крају су студент имали задатак да процене колико су задовољни тиме како су урадили писмени испит.

Резултат t-теста потврдио је постојање статистички значајне разлике у изражености анксиозности између испитаника у тренутном и нормативном узорку Овакав резултат добијен на $\alpha$-скали потврдио је да су студенти проценили испитну ситуацију као стресну, што је послужило као иницијално оправдање да се настави са даљом анализом података. Резултати Анове са поновљеним мерењем указали су на постојање статистички значајних разлика у изражености појединих стратегија суочавања са испитном ситуацијом $(\mathrm{F}(3,330)=100,836, \mathrm{p}<0,001)$. Овде је најизраженија била стратегија суочавање усмерено на проблем, док је најмање изражена била суочавање тражењем помоћи. Показало се и да је задовољство студената тиме како су урадили тест у негативној статистички значајној корелацији са стратегијама суочавања које су усмерене на емоције $(\mathrm{r}=-0,191, \mathrm{p}<0,05)$ и стратегијама суочавања маштање/дистракција $(\mathrm{r}=-0,207, \mathrm{p}<0,05)$.

Статистички значајни предиктори оцене коју су студенти добили су задовољство урађеним испитом, као позитивни предиктор ( $(=0,232 ; \mathrm{p}<0,05)$, и стратегија суочавања маштање/дистракција, као негативни предиктор ( $(=-0,241 ; \mathrm{p}<0,05)$. Могло би се рећи да, иако су резултати указали на то да је суочавање усмерено на проблем најизраженије код студената, суочавање маштање/дистракција је оно које има најнегативнији утицај на успех (субјективно и објективно процењен) на испиту. 